\title{
B34 化学研磨によるガラス研磨の代替可能性 Replaceability of Glass Mirror Polishing by Etching Process
}

\author{
○正 李承福(クリスタル光学), 正 桐野宙治(クリスタル光学), 正 谷泰弘(立命館大学)
}

SeungBok LEE \& Okiharu KIRINO, Crystal Optics Incorporated, 3-4-25 Imakatata, Ohtsu, Shiga Yasuhiro TANI, Ritsumeikan University, 1-1-1 Nojihigashi, Kusatsu, Shiga

Cerium oxide $\left(\mathrm{CeO}_{2}\right)$ abrasives are conventionally used for polishing process of hard-brittle materials, such as crystal and a glass FPD panel. However, the process with cerium oxide abrasives has some problems (1)hard to invade polishing fluid to the center of workpiece in case of large sized panel during processing and (2)hard to cleaning the surface of workpiece after processing and this causes the high processing cost. In order to solve these problems, an abrasive-free pad etching process of glass mirror polishing has proposed for the purpose of replacement of the cerium oxide abrasives. As the result of a series of pad etching tests on the glass workpieces, we have obtained high removal rate and the surface roughness of under $20 \mathrm{~nm}$ Ra.

Key Words Polishing, Etching Process, Polishing Pad, Glass Mirror Surface, Surface Roughness, Abrasive Free, Removal Rate

\section{1. 緒 言}

通常ガラス質工作物の研磨においては、酸化セリウム砥粒という 研磨㶡が多量使用されているが、大型工作物の場合は加工液が中心 部まで浸入しにくい、研磨工程後の洗浄が難しい等の問題があった. しかし、砥粒を使用しない 化学研磨は、工作物と工具の隙間が小さ くても加工液が中心部まで浸入できることと研磨工程後の洗浄が非 常に楽になる.このため、加工コストを低減することが可能となる.

一般的に化学研磨（エッチング）では形状精度が崩れ、高精度が 要求される光学部品や磁気記録部品などには適用できないのが問題 々なっている. 化学研磨面はダメージのない面とはなるが、形状精 度の点では砥粒を使用した研磨に劣るため、適用範用が絞られる可 能性がある、しかし、FPD 基板のように硬度がそれほど高くなく、 しかも人間の目に違和感を与えない程度の形状精度を要求される工 作物の加工には非常に有効な方法となる。

本研究ではガラス質工作物に対してエッチング能力の高いか作 業者と環境なども考慮した化学研磨液の選定およびその実験結果な よ゙を化学研磨によるガラス研磨への代替可能性について報告する.

\section{2. 化学研磨によるガラス研磨}

$2 \cdot 1$ 化学研磨用のエッチング剂砥粒を使わないパッド エッチング研磨法のイメージを図 1 に示す。 パッドの上に化学研 磨片であるエッチング夜を供給しながらパッドと工作物の間にエ ッチング液が浸入し、化学作用およびパッドよ工作物の回転によ る相対速度差により表面仕上げ加工が進める仕組みである。図 2 には検討したエッチング刻の原液を用いて工作物のソーダ板ガ ラスを 10 分間エッチングした基礎実験結果示す.

$2 \cdot 2$ エッチング法を用いたガラス化学研磨実験の目標 砥 粒を使用しないパッドエッチング法による化学研磨の最終目標は 既存のセリア砥粒使用研磨と同等以上の表面粗さや除去能率で仕 上げすることである．第一表面粗さ上しては数ナノメータ、除去 の率としては $1 \mu \mathrm{m} / \mathrm{min}$ 在指している。 な拉、装置や作業者・ 作業環境面なよ゙を考慮し、 $\mathrm{pH}$ は5 5 以上になるようエッチング郕 の調整をすることにした，前節に示した図2は表面が鏡面（粗さ $1.27 \mathrm{~nm})$ のガラスをエッチングした実験結果である. フッ化水素 酸（フッ酸：HF） 上フッ化アンモニウム $\left(\mathrm{NH}_{\mathrm{H}} \mathrm{F}\right)$ の場合快、除去 能率は高いが表面粗さが粗すぎる傾向が分かった，また、硫酸

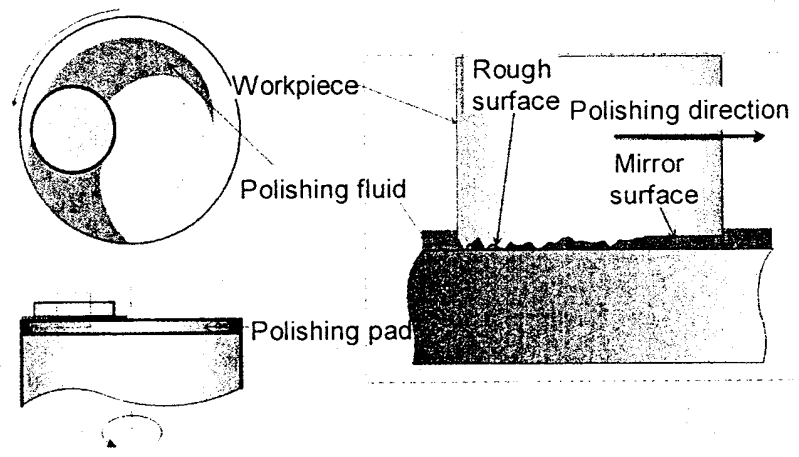

Fig.1 Polishing Image of Pad Etching Process

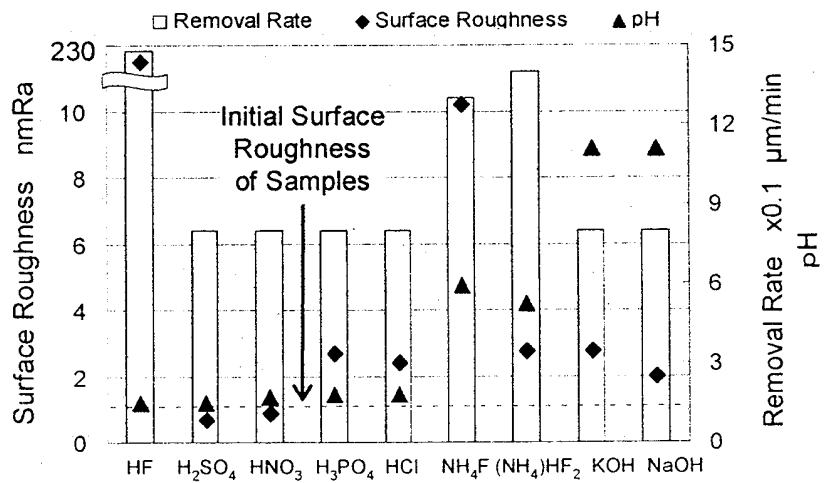

Fig. 2 Characteristics of each Etchant Medicine

$\left(\mathrm{HSO}_{1}\right)$ 上硝酸 $\left(\mathrm{HNO}_{3}\right)$ は、他のエッチング郕と異なる初期粗 さより良い值になることも分からた，表面粗さ、除去能率及び $\mathrm{p}$ $\mathrm{H}$ などの面ではフッ化水素アンモニウム $\left(\mathrm{NH}_{1}\right) \mathrm{HF}$,が良い結果あった.

$$
\text { 3. エッチング剂によるパッドエッチング研磨 }
$$

3.1 パッド面の形状による加工特性＼cjkstart寒験に用意したエポ キシ研磨バッドは 2 種類である. 表面が無気孔タイブの溝無しも の上、エッチング液の浸入老良く寸るため $2 \mathrm{~mm}$ 間隔で深さ $1 \mathrm{~m}$ $\mathrm{m}$ の溝を入れたものを用いて表 1 の研磨条件で実験したバッド面 形状に上万加工特性の結果在図3に示寸。 
Table 1 Conditions of Pad Etching Process

\begin{tabular}{c|c}
\hline \multicolumn{2}{c}{ Etchant Polishing Conditions } \\
\hline PAD & Epoxy Resin \\
\hline Time & $30 \mathrm{~min}$ \\
\hline Pressure & $5 \mathrm{kPa}$ \\
\hline Speed & $40 \mathrm{rpm}$ \\
\hline \multirow{2}{*}{ Workpiece } & Sodalime sheet glass \\
\cline { 2 - 2 } & $20 \mathrm{~mm} \times 20 \mathrm{~mm} \times 5 \mathrm{~mm}$ \\
\hline \hline
\end{tabular}

\begin{tabular}{c|c}
\hline \hline \multicolumn{2}{c}{ Composition of Etchant Solutions } \\
\hline$\left(\mathrm{NH}_{4} \mathrm{~F}\right) \mathrm{HF}_{2}$ & $25 \mathrm{wt} \%$ \\
\hline $\mathrm{H}_{2} \mathrm{SO}_{4}$ & $10 \mathrm{wt} \%$ \\
\hline $\mathrm{H}_{2} \mathrm{O}$ & $65 \mathrm{wt} \%$ \\
\hline $\mathrm{pH}$ & 5.22 \\
\hline
\end{tabular}

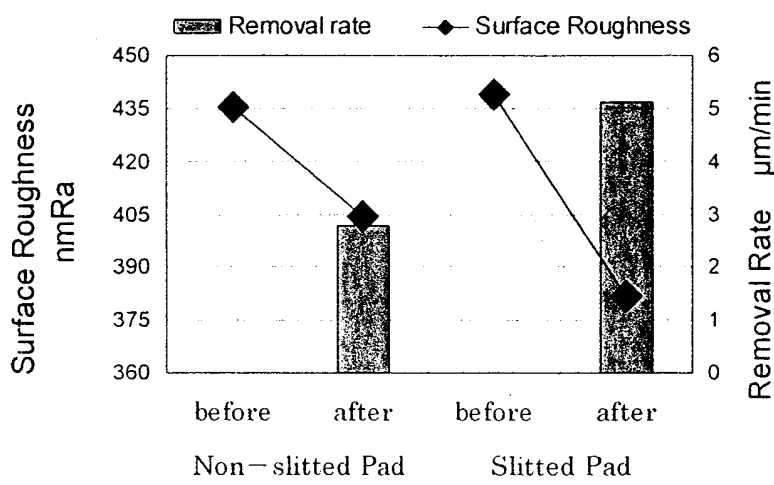

Fig. 3 Characteristics of each Pad after Etching Process

エッチング凬の中、表面粗さ向上に効果的であった 2 種類の硝酸、 硫酸を用いて実験したが硫酸の方がすべての評価項目でよい結果 がでたので実験結果は硫酸を混合したのを示す．加工物はソーダ ガラスで、予め表面を $400 \mathrm{~nm}$ から $500 \mathrm{~nm}$ 程度ラッピングした. この実験結果より溝入り研磨パッドの方が加工物の表面粗さおよ び除去率の面で優れることが確認できた.

$3 \cdot 2$ パッドエッチング法による鏡面加工実験および結果 前節の実験結果から加工時間は鏡面状態に安定するまでにし、他 の実験条件は前節と同じである．図4 には工作物の表面が鏡面ま で安定する時間と加工能率の除去率などを図 5 には粗さ状態の変 化をそれぞれ示す：これらの実験結果から表面粗さは目標とした 値にまだ達してないが除去率はかなり超えていることが分かった. このことは化学研磨液の選定と実験条件などの最適化によりパッ ドエッチング研磨法でガラス研磨法の代替の可能性がみえたと言 える.

\section{4. 結 論}

本研究で得られたおもな結果を以下にまとめる.

・エッチング骫の中で、フッ化水素アンモニウムは除去率の向 上に、硫酸上硝酸の方は工作物の表面粗さ向上に効果的であ ることがわからた。

・ パッドエッチンク研磨用のパッド表面形状は、表面に溝を入 れた方がすべての加工特性（工作物の表面粗さ、除去率）に おいて優れることが確認できた.

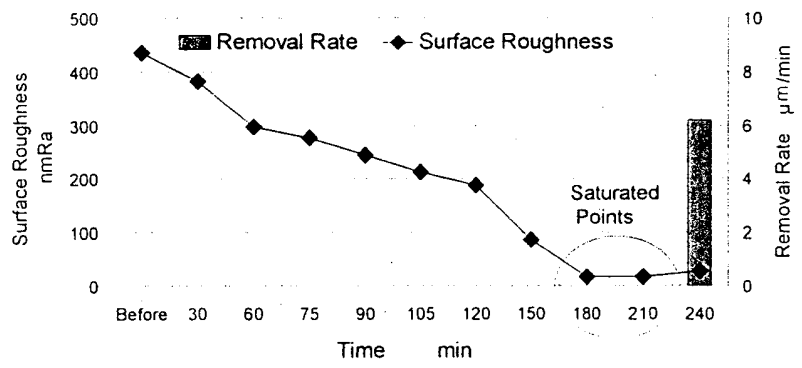

Fig.4 Variations of Surface Roughness and Removal rate

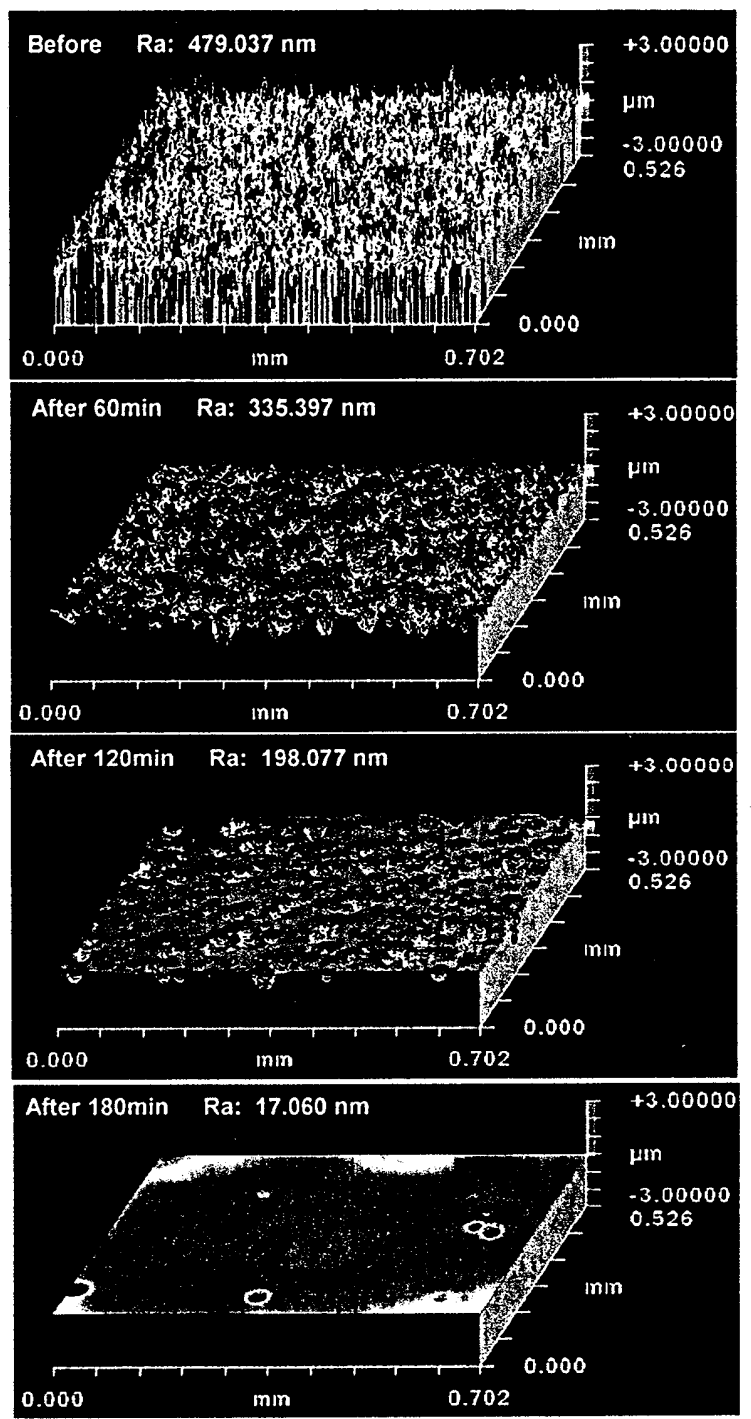

Fig.5 Variations of Surface Roughness by Time

・エエッング刻混合比上研磨条件の最啇化およびパッドの材質、 形状などの最適化でバッドエッチンク研磨法上いった化学研 磨によるガラス研磨への代替可能性が確認できた。

最後に, 本研究はN 100 より精密研磨向け七リウム使用量低減技術 開発拀よび代替材料開発の委託を頂いて行ったことを記して哚く謝 意孛申し上げる. 